\title{
In-vitro antimycobacterial activities of endophytic bacteria associated with medicinal plant of manipur
}

\begin{abstract}
Endophytic bacteria isolated from indigenous medicinal plant Solanum xanthocarpum were screened for antimycobacterial activities against Mycobacterium smegmatis using MTT assays. Of 18 isolates obtained 3 showed antimycobacterial activity. The crude extract of 3 bioactive isolates were tested against attenuated Mycobacterium bovis strain and pathogenic strain of Mycobacterium tuberculosis and their IC50 values were calculated. Crude metabolites of 3 strains showed IC50 values less than $100 \mu \mathrm{g} / \mathrm{ml}$. The 2 bioactive strains were identified as Streptomyces $s p$. and other as Bulkholderia fungorum.
\end{abstract}

Keywords: solanum xanthocarpum, endophytic bacteria, antimycobacterial activities, mtt assay, mycobacterium
Volume 4 Issue 4 - 2017

\author{
Rakhi Khunjamayum,' Tamreihao K,' \\ Debananda S Ningthoujam,' Athokpam \\ Sarita Devi,' Salam Nimaichand, ${ }^{2}$ Sharmistha \\ Banerjee, ${ }^{3}$ Swetha Sankati, ${ }^{3}$ Arshad Rizvi ${ }^{3}$ \\ 'Department of Biochemistry, Manipur University, India \\ ${ }^{2}$ Sun Yat-Sen University, China \\ ${ }^{3}$ Department of Biochemistry, Hyderabad Central University, \\ India
}

\begin{abstract}
Correspondence: Tamreihao K, Department of Biochemistry, Microbial Biotechnology Research Laboratory (MBRL), Manipur University, India, Tel +91 897400 9605, Fax +91 3852435 145/831,Email tammasi2009@gmail.com

Correspondence: Debananda S Ningthoujam, Department of Biochemistry, Microbial Biotechnology Research Laboratory (MBRL), Manipur University, India,Tel +9| 986202 727I, Fax +9| 3852435 |45/83।,

Email debananda.ningthoujam@gmail.com
\end{abstract}

Received: January 29, 2017 | Published: April 13, 2017
Abbreviations: TB, tuberculosis; M. tuberculosis, mycobacterium tuberculosis; MDR, multi-drug resistant; XDR, extensively-drug resistant; SCN, starch casein nitrate agar; $M$. smegmatis, mycobacterium smegmatis; M. bovis, mycobacterium bovis; MTT, 3-(4,5-dimethylthiazol-2-yl)-2,5-diphenyltrtrazolium bromide

\section{Introduction}

Tuberculosis (TB) is a well-known infectious disease caused by Mycobacterium tuberculosis, which commonly affects the lungs. It has afflicted humans since ancient times. Death causes by TB crosses 2 million globally with another 9 million new cases each year. TB is responsible for more years of healthy life lost than any other infectious disease, bar AIDS and malaria. ${ }^{2}$ The major problem with treatment of TB however lies in lack of effective treatment methods. With the emergence of multi-drug resistant (MDR) and extensivelydrug resistant (XDR) strains of M. tuberculosis the disease has become a serious concern. ${ }^{3,4}$ The alarming increase of MDR-TB cases, therefore, requires a urgent development of new, more effective and less toxic side effects with extensive, and potent activity against resistance strains and drugs that will be able to reduce the total duration of treatment. ${ }^{5,6}$

Medicinal plants with a long history of folk medicinal practices offer hope to fulfill the needs of current demands of effective cure. These traditional formulations often contain mixtures of different chemical compounds that may act either individually, additively or synergy to improve health. ${ }^{7}$ There is ample archaeological evidence indicating that medicinal plants were regularly employed by people in prehistoric times. In several ancient cultures, botanical products were ingested for curative and psychotherapeutic purposes. ${ }^{8}$ This traditional knowledge of medicinal plants has usually resulted from trial and error experiment, and often based on speculation and superstition. India is one of the oldest countries in the World with unique wealth of medicinal plants and vast traditional knowledge for use of herbal medicine in curing various diseases. Over the past decade, there has been a proliferation of literature on the antibacterial, antituberculosis, antifungal and antiviral properties of plant extracts. ${ }^{9}$ Several reports on in vitro inhibition of Mycobacterium species by medicinal plant extracts and the bioassay-guided research for antimycobacterial properties from plants have shown sign of success. However no marketable products have been identified till date have reported few metabolites viz. norditerpenoid and 12-demethylmulticauline from the roots of Salivia multicaulis with more potent activity than the first line TB drug ethambutol, and nearly as active as rifampicin under in vitro condition.

Endophytic bacteria from medicinal plants have recently generated significant interest in the search for anti-TB drugs due to their immense potential to contribute to the discovery of new bioactive compounds. Due to close biological association between endophytes and their host plant there is more potential for discovering greater number of bioactive molecules compared to epiphytes or soil related bacteria. ${ }^{10,11}$ The anti-TB produce by endophytes are likely to possess reduced cell toxicity as the bioactive compounds may not affect the eukaryotic host cell due to symbiotic relationship between endophytes and host plants. This is of significance to the medical community as potential anti-TB drugs may not adversely affect human cells. ${ }^{11}$ 
The current study is based on the antimycobacterial screening of endophytic bacteria associated with indigenous medicinal plant of Manipur. It also deals with the study of antimycobacterial activity by crude extracts of bioactive strains.

\section{Materials and methods}

\section{Isolation of endophytic bacteria}

Endophytic bacteria were isolated from roots, stem, leaves and fruits of medicinal plant Solanum xanthocarpum (local name: Leipung-khanga) following the protocols of Qin et al. ${ }^{12}$ Starch Casein Nitrate Agar (SCN), Tap Water peptone Agar, Tap Water Yeast Extract, 2.5\% Water Agar and Yeast Malt Agar were used as isolation medium. The purified cultures were preserved as agar slants $\left(4^{\circ} \mathrm{C}\right)$ and glycerol stocks $\left(20 \% \mathrm{v} / \mathrm{v},-20^{\circ} \mathrm{C}\right)$ for further use. ${ }^{13}$

\section{Primary screening for antimycobacterial activity}

Endophytic isolates were subjected to a preliminary determination of mycobacterial growth arrest and toxicity by culture filtrates (described in the following section) and MTT assays ${ }^{14}$ using Mycobacterium smegmatis (mc2 155) as the indicator. Isolates showing antimycobacterial activity were selected for further experiment. All the experiments were performed in the laboratory (F60) approved by the Institutional Biosafety Committee (N0.UH/SLS/ IBSC/Review/SB-R-11 and SB-R-14) for Mycobacterial cultures by University of Hyderabad Institutional Biosafety Committee under Department of Biotechnology, Govt. of India.

\section{Antimycobacterial activity by culture filtrates}

Strains were inoculated in Starch Casien Nitrate (SCN) broth and kept incubated in a shaker $\left(150 \mathrm{rpm}, 30^{\circ} \mathrm{C}, 7 \mathrm{~d}\right)$. The cultures were centrifuged $(10,000 \mathrm{rpm}$ for $10 \mathrm{mins})$ and the supernatant collected were filtered through a membrane filter $(0.2 \mu \mathrm{m}$ pore size). The pathogenic strain M. smegmatis was grown till the log phase in $7 \mathrm{H} 9^{15}$ media and about $1 \times 10^{6} \mathrm{cfu} / \mathrm{ml}$ of mycobacterium were spread onto the $7 \mathrm{H} 10^{15}$ plates. $100 \mu \mathrm{l}$ of the culture filtrates were then incorporated in a well $(6 \mathrm{~mm})$ and the plates were incubated at $37^{\circ} \mathrm{C}$ for $36 \mathrm{~h}$. Clearing zone surrounding the well indicated antimycobacterial activity.

\section{Extraction of crude metabolites}

Extraction was done according to Kaaria et al., ${ }^{16}$ with some modifications. Bioactive isolates were allowed to grow in $6 \mathrm{~L} \mathrm{SCN}$ broth $\left(150 \mathrm{rpm}, 30^{\circ} \mathrm{C}, 7 \mathrm{~d}\right)$. Culture broth was then centrifuged $(10,000 \mathrm{rpm}, 10 \mathrm{mins})$ and the supernatant collected were extracted two times with ethyl acetate. The organic phase was allowed to pass through a pad of anhydrous sodium sulphate and evaporated to dryness using Rotary Evaporator (Stuart, Bibbly Scientific Limited).

The extracts were used for determining the cytotoxicity assay against attenuated $M$. bovis BCG and pathogenic strain of $M$. tuberculosis H37Rv. Mycobacterium strains were allowed to grow in $7 \mathrm{H} 9$ media supplemented with 10\% Oleic Albumin Dextrose Catalase (OADC) till the $\log$ phase and about $1 \times 10^{6} \mathrm{cfu} / \mathrm{ml}$ were seeded into microplate, incubated for $24-36$ hours at $37^{\circ} \mathrm{C}$. Inculum size was prepared using Macfarland standards ( 0.1 OD600 corresponds to $1 \times 10^{8} \mathrm{cfu} / \mathrm{ml}$. $20 \mu \mathrm{l}$ of $\quad 5 \mathrm{mg} / \mathrm{ml} \quad 3$-(4,5-dimethylthiazol-2-yl)-2,5-diphenyltrtrazolium bromide (MTT) was added to each well and incubated for $4 \mathrm{~h}$. The formazan crystals formed were dissolved in DMSO and the plates were read at $540 \mathrm{~nm}$ in Enzyme-linked immunosorbent assay (ELISA reader) and IC50 values were calculated.

\section{Characterization of bioactive strains}

Genomic DNA isolation was done according to $\mathrm{Li}$ et al. ${ }^{17}$ The $16 \mathrm{~S}$ rRNA gene sequence was amplified using the primers $8 \mathrm{~F}$ (5'-CAGAGTTTGATCCTGGCT-3') and 1522R (5'-AGGAGGTGATCCAGCCGCA-3') (IDT, USA). The primers were designed based on the 16S rRNA gene sequence of E. coli. ${ }^{18}$ The almost complete 16S rRNA gene sequence of the strain was identified using the EzTaxon-e server database ${ }^{19}$ and aligned with the 16S rRNA gene sequences of related species using CLUSTAL X version 2.1. ${ }^{20}$

\section{Results and discussion}

Traditionally, soil-derived bacteria have been most frequently screened for bioactive compounds against $M$. tuberculosis. Unfortunately, the frequency of finding new bioactive compounds from normal soil-derived bacteria is declining because of the redundancy in the isolation of known bacteria and antibiotics. Alternatively, bacteria from previously unexplored or under explored environments such as medicinal plants, marine, desert and forest ecosystems are screened. ${ }^{21}$ In recent years, pathogenic microorganisms are gaining resistance against antimicrobial agents; hence the search for new, safe and more effective antimicrobial agents is an urgent need for the emerging multidrug resistance. ${ }^{6}$ Endophytes from medicinal plants have recently given significance due to their immense potential to contribute to the discovery of novel anti-TB compounds. Endophytic bacteria have been reported to possess wide spectrum activity against many pathogenic fungi and bacteria. ${ }^{22,23}$

A total of 18 putative strains were isolated from medicinally important plant of Manipur. Based on the preliminary screening for antimycobacterial activity against $M$. smegmatis, 3 most promising isolates viz. SxF1 (isolated from Fruit), SxF2 (Fruit) and SxL6 (Leaves) were selected for study. The culture filtrates of the 3 strains also exhibited clearing zone of inhibition against $M$. smegmatis.

Crude extract strains SxF1 and SxL6 showed showed good antimycobacterial activity with IC50 values of 25 and $12.5 \mu \mathrm{g} / \mathrm{ml}$. However, the IC50 value of SxF2 was larger than 100 (Table 1) (Figure 1). Crude extract of strains SxF1, SxF2 and SxL6 showed IC50 values of less than $100 \mu \mathrm{g} / \mathrm{ml}$ against $\mathrm{H} 37 \mathrm{Rv}$. The extracts from SxF2 though effective against $M$. bovis BCG $(\mathrm{IC} 50=22.6 \mu \mathrm{g} / \mathrm{ml})$ was not as effective against M. tuberculosis H37Rv (IC50=652 $\mu \mathrm{g}$ / ml) (Table 1). The culture filtrates and crude metabolites extract of Streptomyces $s p$. has been reported to exhibit antimycobacterial activity against $M$. tuberculosis H37RV., ${ }^{6,24}$ Similarly, culture filtrate and crude extract of Brevibacillus laterosporus isolated from soil inhibit the growth of Mycobacterium $s p .{ }^{25}$ Penialidin C produced by endophytic fungi Penicillium $s p$. showed antimycobacterial activity against $M$. smegmatis. ${ }^{26}$ Strain SxF1 was found to be closely related to Streptomyces harbinensis (99.51\%), SxL6 was closely related to Streptomyces herbinensis $(99.76 \%)$. SxF2 was identified as Bulkholderia fungorum (100\%). To our knowledge, this is the first report of Bulkholderia sp. having antimycobacterial activity. ${ }^{27-32}$ 


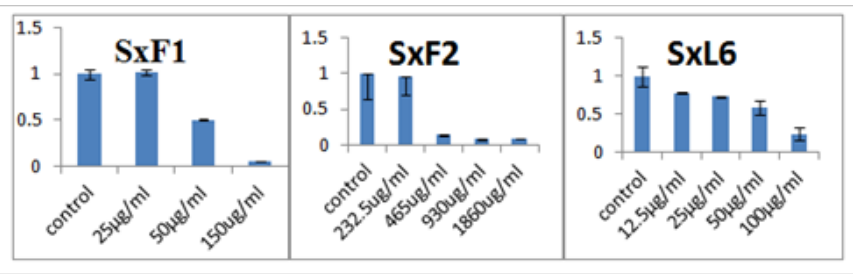

Figure I MTT assay for Mycobacterium smegmatis using ethyl acetate extract of culture filtrate. Note: $X$ axis, amount of extracts (in $\mathrm{mg} / \mathrm{ml}$ ); $Y$ axis, relative viability

Table I IC 50 values of the crude extracts of bioactive strains

\begin{tabular}{llll}
\hline S. no. & Isolate & M. Bovis (BCG) & M. Tuberculosis (H37Rv) \\
\hline 1 & SxL6 & $83.76 \mu \mathrm{g} / \mathrm{ml}$ & $62.48 \mu \mathrm{g} / \mathrm{ml}$ \\
2 & SxF1 & $24.902 \mu \mathrm{g} / \mathrm{ml}$ & $74.70 \mu \mathrm{g} / \mathrm{ml}$ \\
3 & SxF2 & $22.6 \mu \mathrm{g} / \mathrm{ml}$ & $652.5 \mu \mathrm{g} / \mathrm{ml}$ \\
\hline
\end{tabular}

\section{Conclusion}

Of 18 endophytic bacteria obtained from medicinal plant Solanum xanthocarpum, 3 strains showed antimycobacterial activity under primary screening. Crude metabolites of the 3 strains also exhibited good antimycobacterial activity against the tested Mycobacterium sp. However, crude extract of Bulkholderia fungorum was not effective against M. tuberculosis H37Rv. The antimycobacterial compound(s) release by the bioactive strains can be used for further study for development of new, more effective and safer anti-tuberculosis in order to control the alarming increase of MDR-TB cases in the developing country especially India.

\section{Acknowledgements}

Authors gratefully acknowledged Department of Biotechnology (DBT), Government of India (GOI) for funding DBT Twinning Programme (BT/47/NE/TBP/2010). Authors also acknowledge the grant from DBT, GOI given to the DBT-State Biotech Hub (DBTSBTHub) (BT/04/NE/2009), Department of Biochemistry, Manipur University.

\section{Conflict of interest}

The author declares no conflict of interest.

\section{References}

1. Tsara V, Serasli E, Christaki P. Problems in diagnosis and treatment of tuberculosis infection. Hippokratia. 2009;13(1):20-22.

2. Corbett EL, Watt CJ, Walker N, et al. The growing burden of tuberculosis: global trends and interactions with the HIV epidemic. Arch Internal Med. 2003;163(9):1009-1021.

3. Venkataraman P, Paramasivan CN. Drug resistance in tuberculosis and issues related to multi-drug resistance in planning for TB control in India. Health Administrator. 2003;15:127-136.

4. Pandya K, Patel P, Patel G, et al. In vitro Anti-mycobacterial study of essential oil of few selected plants - Part 2. International Journal of Universal Pharmacy and Bio Sciences. 2012;2(2):150-155.

5. Harley RM, Atkins S, Budantsev A, et al. The families and genera of vascular plants. 7th ed. Germany: Springer Verlag; 2004. p. 167-275.
6. Radhakrishnan M, Suganya S, Balagurunathan R, et al. Preliminary screening for antibacterial and antimycobacterial activity of actinomycetes from less explored ecosystems. World J Microbiol Biotechnol. 2010;26(3):561-566.

7. Radhakrishnan M, Balagurunathan R, Selvakumar N, et al. Bioprospecting of marine derived actinomycetes with special reference to antimycobacterial activity. Ind J Geo-Marine Sc. 2011;40(3):407-410.

8. Heinrich M, Gibbons S. Ethnopharmacology in drug discovery: an analysis of its role and potential contribution. J Pharm Pharmacol. $2001 ; 53(4): 425-32$.

9. Halberstein R. Medicinal plants: historical and cross-cultural usage patterns. Ann Epidemiol. 2005;15(9):686-699.

10. Newton SM, Lau C, Wright CW. A Review of antimycobacterial natural products. Phytother Res. 2000;14(5):303-322.

11. Strobel G, Daisy B. Bioprospecting for microbial endophytes and their natural products. Microbiol Mol Biol Rev. 2003;67(4):491-502.

12. Alvin A, Miller KI, Neilan BA. Exploring the potential of endophytes from medicinal plants as sources of antimycobacterial compounds. Microbiol Res. 2014;169(7-8):483-495.

13. Qin S, Wang HB, Chen HH, et al. Glycomyces endophyticus sp. nov., an endophytic actinomycete isolated from the root of Carex baccans Nees. Int J Syst Evol Microbiol. 2008;58(pt 11):2525-2528.

14. Tamreihao K, Nimaichand S, Chanu SB, et al. Acidotolerant Streptomyces $s p$. MBRL 10 from limestone quarry site showing antagonism against fungal pathogens and growth promotion in rice plants. Journal of King Saud University-Science. 2016.

15. Montoro E, Lemus D, Echemendia M, et al. Comparative evaluation of the nitrate reduction assay, the MTT test, and the resajurin micrititre assay for drug susceptibility testing of clinical isolates of mycobacterium tuberculosis. J Antimicrob Chemother. 2005;55(4):500-505.

16. Kaaria P, Matiru V, Ndungu M. Antimicrobial activities of secondary metabolites produced by endophytic bacteria from selected indigenous Kenyan plants. Afr J Microbio Res. 2012;6(45):7253-7258.

17. Li WJ, Xu P, Schumann P, et al. Georgenia ruanii sp. nov., a novel actinobacterium isolated from forest soil in yunnan (China), and emended description of the genus georgenia. Int J Syst Evol Microbiol. 2007;57(pt 7):1424-1428.

18. Marchesi JR, Sato T, Weightman AJ, et al. Design and evaluation of useful bacterium-specific PCR primers that amplify genes coding for bacterial 16S rRNA. Appl Environ Microbiol. 1998;64(2):795-799.

19. Kim OS, Cho YJ, Lee K, et al. Introducing EzTaxon-e: a prokaryotic 16S rRNA Gene sequence database with phylotypes that represent uncultured species. Int J Syst Evol Microbiol. 2012;62(pt 3):716-721.

20. Larkin MA, Blackshields G, Brown NP, et al. Clustal wand clustal X version 2.0. Bioinformatics. 2007;23(21):2947-2948.

21. Berdy J. Bioactive microbial metabolites. J Antibiot (Tokyo). 2005;58(1):126.

22. Castillo U, Strobel GA, Ford EJ, et al. Munumbicins, wide spectrum antibiotics produced by Streptomyces munumbi, endophytic on Kennedia nigriscans. Microbiology. 2002;148(pt 9):2675-2685.

23. Seo WT, Lim WJ, Kim EJ, et al. Endophytic bacterial diversity in the young radish and their antimicrobial activity against pathogens. $J$ Korean Soc Appl Bio Chem. 2010;53(4):493-503.

24. Radhakrishnan M, Balagurunathan R, Selvakumar N, et al. Bioprospecting of marine derived actinomycetes with special reference to antimycobacterial activity. Ind J Geo Marine Sc. 2011;40(3):407-410. 
25. Hassi M, Guendouzi SE, Haggoud A, et al. Antimycobacterial activity of a Brevibacillus laterosporus strain isolated from a Moroccan soil. Braz J Microbiol. 2012;43(4):1516-1522.

26. Jouda JB, Mawabo IK, Notedji A, et al. Anti-mycobacterial activity of polyketides from Penicillium sp. endophyte isolated from Garcinia nobilis against Mycobacterium smegmatis. Int J Mycobacteriol. 2016;5(2):192196.

27. Bauer AW, Kirby WM, Sherris JC, et al. Antibiotic susceptibility testing by a standardized single disk method. Am J Clin Pathol. 1966;45(4):493-496.

28. Brewer TF, Heymann SJ. To control and beyond: moving towards eliminating the global tuberculosis threat. J Epidemiol Community Health. 2004;58(10):822-825.
29. Hui Sun, Yan He, Qing Xiao, et al. Isolation, characterization, and antimicrobial activity of endophytic bacteria from Polygonum cuspidatum. Afr J Microbiol Res. 2013;7(16):1496-1504.

30. Madigan MT, Martinko JM, Parker J. Brock biology microrganisms. 8th ed. USA: Prentice Hall International Inc; 1997. p. 440-442.

31. Razzagh Mahmoudi. An overview of using some essential oils in functional dairy products from Iran. Malaysian J Sci. 2014;33(1):3-8.

32. Yuan WM, Crawford DL. Characterization of Streptomyces lydicus WYEC 108 as a potential biocontrol agent against fungal root and seed rots. Appl Environ Microbiol. 1995;61(8):3119-3128. 